Safety and immunogenicity of Russian live-attenuated and US inactivated trivalent influenza vaccines in the elderly. In: Brown LE, Hampson $\mathrm{AW}$, Webster RG, eds. Options for the Control of Influenza III. Amsterdam, The Netherlands: Elsevier Science BV; 1996:572-578.

39. Treanor JJ, Mattison HR, Dumyati G, Yinnon A, Erb S, O'Brien D, et al Protective effect of combined live intranasal and inactivated influenza $A$ vaccines in the elderly. Ann Intern Med 1992;117:625-633.

40. Tominack RL, Hayden FG. Rimantadine hydrochloride and amantadine hydrochloride use in influenza A virus infections. Infect Dis Clin North Am 1987;1:459-478.

41. Calfee DP, Hayden FG. New approaches to influenza chemotherapy: neuraminidase inhibitors. Drugs 1998;56:537-553.

42. Hayden FG, Osterhaus AD, Treanor JJ, Fleming DM, Aoki FY, Nicholson KG, et al. Efficacy and safety of the neuraminidase inhibitor zanamivir in the treatment of influenzavirus infections. GG167 Influenza Study Group. N Engl J Med 1997;337:874-880.

43. Aoki F, Osterhaus A, Rimmelzwaan G, Kinnersley N, Ward P. Oral GS4104 successfully reduces duration and severity of naturally acquired influenza. In: Final Program and Exhibits Addendum of the 38th Interscience Conference on Antimicrobial Agents and Chemotherapy; September 24-28, 1998: San Diego, CA. Abstract LB-5.

44. The Mist Study Group. Randomized trial of efficacy and safety of inhaled zanamivir in treatment of influenza A and B virus infections. Lancet 1998; $352: 1877-1881$

45. Monto AS, Robinson DP, Herlocher ML, Hinson JM, Elliott MJ, Crisp A. Zanamivir in the prevention of influenza among healthy adults: a randomized controlled trial. JAMA 1999;282:31-35.

46. Hayden FG, Atmar R, Schilling M, et al. Safety and efficacy of oral GS4104 in long term prophylaxis of natural influenza. In: Final Program and Abstracts of the 38th Interscience Conference on Antimicrobial Agents and Chemotherapy; September 24-28, 1998; San Diego, CA Abstract LB-6.

47. Relenza [package insert]. Research Triangle Park, NC: Glaxo Wellcome Inc; 1999.

48. Daniel MJ, Barnett JM, Pearson BA. The low potential for drug interactions with zanamivir. Clin Pharmacokinet 1999;36(suppl 1):41-50.

49. Tamiflu [package insert]. Nutley, NJ: Roche Laboratories Inc; 1999.

50. Colacino JM, Laver WG, Air GM. Selection of influenza A and B viruses for resistance to 4-guanidino-Neu5Ac2en in cell culture. J Infect Dis 1997;176(suppl 1):S66-S68.
51. Gubareva LV, Bethell R, Hart GJ, Murti KG, Penn CR, Webster RG. Characterization of mutants of influenza A virus selected with the neuraminidase inhibitor 4-guanidino-Neu5Ac2en. $J$ Virol 1996;70:18181827.

52. Blick TJ, Tiong T, Sahasrabudhe A, Varghese IN, Colman PM, Hart GJ, et al. Generation and characterization of an influenza virus neuraminidase variant with decreased sensitivity to the neuraminidase-specific inhibitor 4-guanidino-Neu5Ac2en. Virology 1995;214:475-484.

53. Tai CY, Escarpe PA, Sidwell RW, Williams MA, Lew W, Wu H, et al. Characterization of human influenza virus variants selected in vitro in the presence of the neuraminidase inhibitor GS 4071. Antimicrob Agents Chemother 1998:42:3234-3241.

54. Monto AS, Arden NH. Implications of viral resistance to amantadine in control of influenza A. Clin Infect Dis 1992;15(suppl 1):362-367.

55. Mast EE, Harmon MW, Gravenstein S, Wu SP, Arden NH, Circo R, et al. Emergence and possible transmission of amantadine-resistant viruses during nursing home outbreaks of influenza A (H3N2). Am J Epidemiol 1991:13:988-997.

56. Hayden FG, Belshe RB, Clover RD, Hay AJ, Oakes MG, Soo W. Emergence and apparent transmission of rimantadine-resistant influenza A virus in families. $N$ Engl J Med 1989;321:1696-1702.

57. Hayden FG, Hay AJ. Emergence and transmission of influenza A viruses resistant to amantadine and rimantadine. Curr Top Microbiol Immunol 1992:176:120-130.

58. Gomolin HG, Leib HB, Arden NH, Sherman FT. Control of influenza outbreaks in the nursing home: guidelines for diagnosis and management. I Am Geriatr Soc 1995:43:71-74.

59. Staynor K, Foster G, McArthur M, McGeer A, Petric M, Simor AE. Influenza A outbreak in a nursing home: the value of early diagnosis and the use of amantadine hydrochloride. Can I Infect Control 1994;9:109-111.

60. Leonardi GP, Leib H, Birkhead GS, Smith C, Costello P, Conron W. Comparison of rapid detection methods for influenza $\mathrm{A}$ virus and their value in health-care management of institutionalized geriatric patients. $J$ Clin Microbiol 1994;32:70-74.

61. Zstat flu [product package insert]. Oklahoma City, OK: ZymeTx Inc; 1998. 62. Flu OIA [product package insert]. Boulder, CO: BioStar, Inc; 1999.

63. Bradley SF, the Long-Term-Care Committee of the Society for Healthcare Epidemiology of America. Prevention of influenza in longterm-care facilities. Infect Control Hosp Epidemiol 1999;20:629-637.

\title{
Comparison of Nosocomial Infections in Trauma and Surgical Patients
}

\section{Gina Pugliese, RN, MS Martin S. Favero, $\mathbf{P h D}$}

Wallace and colleagues from the Division of Trauma Surgery and Critical Care, University of California-Irvine Medical Center, conducted a study to determine whether there is a difference in rates of nosocomial infections between trauma and surgical patients in the SICU. From January 1995 through December 1997 , they reviewed 1,272 trauma and 2,443 surgical admissions to SICU. They documented all cases of nosocomial pneumonia, urinary tract infections, bloodstream infections, and surgicalsite infections. From these data they determined infection rates per 100 admissions. They also identified all device-related nosocomial infections and calculated infection rates by current CDC standards (number of device infections $\div$ number of devicedays $\times 1,000$ ). They found that the overall trauma patient infection rate was $11.6 \%$ compared with $6.4 \%$ for surgical patients $(P<.001)$. Using conventional infection-rate criteria, trauma patients had higher frequencies of ventilator-associated pneumonia $(6.1 \%$ vs $2.5 \% ; P<0.001)$, urinary tract infection $(2.4 \%$ vs $1.8 \% ; P<0.2)$, and bloodstream infection $(2.5 \%$ vs $1.3 \% ; P<0.01)$. However, when using the CDC guidelines, which correct for the number of device-days for infections, only the difference in rate of pneumonia between the two groups reached statistical sig- nificance (23.9 for trauma patients vs 16.7 for the surgery group; $P<.005$ ).

The authors concluded that trauma patients are at higher risk for nosocomial infections than routine surgical patients. Because of this difference, centers should collect and report data separately for trauma and surgical patients in the ICU. Specific attention should be focused on the causes and prevention of increased rates of nosocomial pneumonia in trauma patients.

FROM: Wallace WC, Cinat $M$, Gornick WB, Lekawa ME, Wilson SE. Nosocomial infections in the surgical intensive care unit: a difference between trauma and surgical patients. Am Surg 1999;65:987-990. 